\section{Problematika Mahasiswa Pendidikan Bahasa Jerman Yang Belum Pernah Mendapatkan Pelajaran bahasa Jerman Di Jenjang Pendidikan Sebelumnya}

\author{
Ihsan', Syarifah Fathimah Al Ilmul ${ }^{2}$ \\ Universitas Negeri Makassar
}

Email: ihsansansss@gmail.com

\begin{abstract}
Abstrak. Penelitian ini bertujuan untuk mengetahui problematika yang dialami oleh mahasiswa pendidikan bahasa Jerman yang belum pernah mendapatkan pelajaran bahasa Jerman dijenjang pendidikan sebelumnya.. Jenis penelitian ini adalah deskriptif kualitatif. Populasi dalam penelitian ini adalah mahasiswa Program Studi Pendidikan Bahasa Jerman. Universitas Negeri Makassar angkatan 2019. Sampel dalam penelitian ini adalah mahasiswa angkatan 2019 yang belum pernah belajar bahasa Jerman dijenjang pendidikan sebelumnya. Pengambilan data dilakukan melalui observasi dan angket.Hasil yang diperoleh pada penelitian ini yaitu masalah-masalah yang dihadapi dalam proses pembelajaran meliputi faktor internal dan eksternal. Faktor internal meliputi kemampuan menyimpan perolehan bahan ajar, menggali hasil belajar yang tersimpan, dan kebiasaan belajar. Sedangkan faktor eksternal meliputi sarana dan prasarana penunjang akademik, kebijakan penilaian tenaga pendidik, dan lingkungan social di kampus. Masalah/kendala utama adalah kurangnya penguasaan kosakata yang dimiliki, kesulitan dalam struktur kalimat (gramatik) dan kurangnya kemampuan dalam pengucapan/pelafalan.
\end{abstract}

Kata Kunci: Problematika, Bahasa Jerman

\section{INTERFERENCE \\ Journal of Language, \\ Literature,and \\ Linguistics}

\section{E-ISSN: 2721-1835 \\ P-ISSN: 2721-1827}

Submitted : May $3^{\text {rd }}, 2021$

Accepted : May $24^{\text {th }}, 2021$

Abstract. This study is aimed at knowing the problematics of german education students who have never gotten german lessons in previous education levels. This study belongs to descriptive qualitative. The population in this study is German Education students of State University of Makassar, class of 2019. The samples in the study are students of the class of 2019 who have never learned German in previous education level. The data were collected from observation and questionnaires. The results of the study are problems faced in the learning process including internal factors and external factors. The internal factors are the ability to memorize teaching materials, explore memorized teaching materials, and learning habit. Whilst external factors are academic facilities and infrastructure, teaching staff assessment policies, and the social environment on campus. The main problems are: the lack of vocabulary, difficulties in sentences structure (grammar) and the lack of ability in pronunciation. 


\section{PENDAHULUAN}

Bahasa merupakan salah satu bagian dalam kebudayaan yang ada pada masyarakat. Bahasa terdiri atas bahasa lisan dan tulisan. Sebagai bagian dari kebudayaan, manusia memegang peranan penting. Bahasa juga turut berperan karena fungsinya sebagai alat komunikasi yang terus berkembang sesuai dengan perkembangan peradaban manusia.

Jurusan Bahasa Jerman sudah banyak terdapat pada perguruan tinggi negeri maupun swasta yang ada di Indonesia. Universitas Negeri Makassar adalah salah satu perguruan tinggi yang menyediakan Strata 1 (S1) Pendidikan Bahasa Jerman. Program studi pendidikan bahasa Jerman menerima mahasiswa baru setiap tahun dengan 3 jalur yakni, Seleksi Nasional Masuk Perguruan Tinggi Negeri (SNMPTN), Seleksi Bersama Masuk Perguruan Tinggi Negeri (SBMTN), dan jalur Mandiri. Mahasiswa baru program studi pendidikan bahasa Jerman berasal dari berbagai sekolah dan asal daerah yang beragam. Hal ini memunculkan beragam problematika saat mahasiswa baru memulai belajar di program studi pendidikan bahasa Jerman.

Berdasarkan hasil observasi yang dilakukan di program studi pendidikan bahasa Jerman, jurusan bahasa Asing, Universitas Negeri Makassar, ada beberapa problematika yang dialami mahasiswa diantaranya bagi mahasiswa baru yang belum mendapatkan pelajaran bahasa Jerman di jenjang pendidikan sebelumnya merasa sulit dalam pembelajaran bahasa Jerman. Beberapa dari mereka merasa kurang dapat bersaing dengan mahasiswa yang lain yang telah memiliki basic pelajaran bahasa Jerman di jenjang pendidikan sebelumnya. Hal tersebut senada dengan pengalaman beberapa teman angkatan peneliti yang tidak memiliki basic pelajaran bahasa Jerman sebelumnya merasa kurang dapat bersaing ataupun mengikuti mahasiswa yang lain dalam proses pembelajaran selama perkuliahan. Pada penelitian ini kita akan melihat apa yang sebenarnya menjadi problematika yang memepengaruhi mahasiswa dalam bahasa Jerman.

Beberapa sebelumnya yang relevan dengan penelitian ini yang dilakukan oleh Pabumbun (2019) di SMA Negeri 11 Makassar menyimpulkan bahwa problematika pembelajaran bahasa Jerman terdiri dari masalah internal meliputi penguasaan aspek kebahasaan lainnya, minat, persepsi, fisik, dan psikologis sedangkan faktor eksternal meliputi lingkungan, guru, bahan ajar, sarana dan prasarana. Selain itu, Setiyawan (2018) menyatakan bahwa sedikitnya ada 7 problem pembelajaran yang disebabkan oleh adanya latar belakang dalam pendidikan mahasiswa Universitas Negeri Sunan Kalijaga Yogyakarta. Sejalan dengan penelitian yang dilakukan oleh Wibowo (2010) Hambatan belajar Mahasiswa input non pesantren dan non Aliyah dalam belajar bahasa Arab di jurusan sastra Arab Universitas Negeri Malang menyatakan bahwa tujuan khusus dalam penelitian ini adalah untuk mendeskripsikan (1) hambatan internal mahasiswa dalam belajar bahasa Arab, (2) hambatan eksternal dalam belajar bahasa Arab. Selanjutnya hasil penelitian yang dilakukan oleh (Nugroho, G. E., 2019; Besse Wahida, M. P. I., 2017; Amirudin, N., 2017) bahwa problematika dalam mempelajari bahasa asing, khususnya bahasa Arab adalah problamtika terkait dengan mahasiswa/siswa, dosen/guru, metode, dan alokasi waktu serta sarana dan media pembelajaran. 


\section{METODE PENELITIAN}

Jenis penelitian yang digunakan yakni deskriptif kualitatif dimaksudkan untuk memperoleh informasi mengenai masalah-masalah mahasiswa yang belum pernah belajar bahasa Jerman dijenjang sebelumnya.

Subjek penelitian ini adalah mahasiswa Program Studi Pendidikan Bahasa Jerman Jurusan Bahasa Asing Fakultas Bahasa dan Sastra Universitas Negeri Makassar angkatan 2019 yang belum pernah belajar bahasa Jerman dijenjang pendidikan sebelumnya. Pelaksanaan penelitian dilakukan pada tahun ajaran 20202021 di Program Studi Pendidikan Bahasa Jerman Jurusan Bahasa Asing Fakultas Bahasa dan Sastra Universitas Negeri Makassar.

Populasi dalam penelitian ini adalah mahasiswa Program Studi Pendidikan Bahasa Jerman Jurusan Bahasa Asing Fakultas Bahasa dan Sastra Universitas Negeri Makassar angkatan 2019. Sampel yang digunakan dalam penelitian ini adalah purpose sampling yakni mahasiswa angkatan 2019 yang belum pernah belajar bahasa Jerman dijenjang pendidikan sebelumnya. Definisi operasional yang dibahas dalam penelitian ini terbatas yakni problematika mahasiswa, pelajaran bahasa Jerman, dan jenjeang pendidikan sebelumnya.

Teknik pengumpulan data dalam penelitian ini, menggunakan Teknik yang bersifat menggabungkan dari berbagai teknik pengumpulan data dan sumber data yang telah ada yang meliputi observasi, wawancara dan angket. Instrumen penelitian ini yakni instrumen utama. Instrumen utama dalam penelitian ini adalah peneliti sendiri. Peneliti memilih informan (mahasiswa) sebagai sumber data, melakukan pengumpulan data problematika yang dialami kemudian menilai kualitas data, menganalisis data, menafsirkan data, dan membuat kesimpulan atas data penelitian yang didapat. Data yang telah diperoleh akan dianalisis secara kualitatif serta diuraikan dalam bentuk deskriptif.

\section{HASIL DAN PEMBAHASAN}

Hasil yang diperoleh pada penelitian ini menggambarkan masalah-masalah mahasiswa pendidikan bahasa Jerman yang belum pernah mendapatkan pelajaran bahasa Jerman di jenjang pendidikan sebelumnya akan dianalisis berdasarkan observasi, angket terbuka dan tertutup yang diberikan kepada mahasiswa.

\section{Observasi}

Berdasarkan observasi yang dilakukan terdapat 18 mahasiswa yang belum pernah belajar bahasa Jerman dan masalah-masalah yang dihadapi secara umum berdasarkan faktor internal dan eksternal yang terdiri dari 16 poin gambaran perilaku mahasiswa.

Masalah-masalah yang dihadapi mahasiswa berdasarkan faktor internal meliputi sikap mahasiswa dalam menerima materi pembelajaran bahasa Jerman, motivasi dalam belajar, konsentrasi saat pembelajaran berlangsung, kemampuan dalam mengolah bahan ajar, kemampuan dalam menyimpan perolehan bahan ajar, proses menggali hasil belajar, perolehan nilai dalam menyelesaikan latihan atau tugas, rasa percaya diri saat melangsungkan proses pembelajaran, kebiasaan belajar diluar dari pembelajaran bahasa Jerman, hubungan antara impian/cita-cita dalam pembelajaran bahasa Jerman yang sedang di tempuh, dan gangguan fungsi alat 
indera dan alat perseptual yang mempengaruhi proses pembelajaran. Sedangkan faktor eksternal meliputi tugas tenaga pendidik, sarana dan prasarana penunjang akademik, kebijakan penilaian tenaga pendidik, lingkungan sosial di kampus dan lingkungan keluarga.

\section{Deskripsi Analisis Data Angket}

\section{a. Angket Terbuka}

1. Sikap terhadap belajar.

Sikap mahasiswa dalam memberikan penilaian tentang sesuatu yang membawa diri sesuai dengan penilaian, sehingga adanya penilaian tentang sesuatu, mengakibatkan terjadinya sikap menerima, menolak atau mengabaikan. Sejalan dengan teori Dimyati dan Sudjiono (2010:235) mengatakan bahwa salah satu faktor internal yang menjadi problematika pembelajaran adalah sikap belajar mahasiswa, namun dalam penelitian ini hal tersebut tidak menjadi problematika karena semua mahasiswa menyatakan menerima materi pembelajaran bahasa Jerman.

2. Motivasi Belajar.

Motivasi belajar berkaitan dengan kekuatan mental yang mendorong terjadinya proses belajar. Sejalan dengan teori Dimyati dan Sudjiono (2010:235) mengatakan bahwa salah satu faktor internal yang menjadi problematika pembelajaran adalah motivasi dalam belajar dan hal tersebut menjadi salah satu problematika yang didapat karena masih ada beberapa mahasiswa yang kurang semangat atau tekun dalam proses pembelajaran. Menurut Yusri, et.all. (2018) motivasi dipengaruhi oleh beberapa faktor diantaranya seperti faktor intrinsik dan ekstrinsik. Motivasi belajar akan meningkat jika mendapatkan kegiatan yang menarik dalam belajar. Begitupun sebaliknya, motivasi belajar akan menurun jika ia tidak mendapatkan kegiatan yang menarik dalam proses pembelajaran. Maka dari itu, sangat penting untuk membuat proses pembelajaran semenarik mungkin sehingga siswa/mahasiswa akan tertarik untuk mengikuti proses pembelajaran.

\section{Konsentrasi Belajar}

Kesulitan berkonsentrasi salah satu indikator terjadinya masalah terhadap pembelajaran yang dihadapi mahasiswa, sebab hal itu menjadi kendala dalam mencapai hasil belajar yang diharapkan. Sejalan dengan teori Dimyati dan Sudjiono (2010:235) mengatakan bahwa salah satu faktor internal yang menjadi problematika pembelajaran adalah konsentrasi dalam belajar, dapat dilihat sebagian mahasiswa kurang konsentrasi dalam proses pembelajaran bahasa Jerman berlangsung.

\section{Kemampuan Mengolah Bahan Ajar}

Kemampuan mahasiswa untuk menerima isi dan cara pemerolehan ajaran sehingga menjadi bermakna bagi mahasiswa. Sejalan dengan teori Dimyati dan Sudjiono (2010:235) mengatakan bahwa salah satu faktor internal yang menjadi problematika pembelajaran adalah kemampuan dalam mengolah bahan ajar. Kesulitan mahasiswa didalam mengolah bahan ajar dibutuhkan bantuan pengajar sehingga dapat mendorong mahasiswa agar lebih memiliki kemampuan sendiri 
untuk terus mengolah bahan belajar. Beberapa mahasiswa masih kurang baik dalam mengolah bahan ajar yang diterima saat proses pembelajaran bahasa Jerman.

5. Kemampuan Menyimpan Perolehan Hasil Belajar

Kemampuan menyimpan isi pesan dan cara perolehan pesan dapat berlangsung dalam waktu lama yang berarti hasil belajar tetap dimiliki mahasiswa dan dapat berlangsung pendek yang berarti hasil belajar cepat dilupakan. Sejalan dengan teori Dimyati dan Sudjiono (2010:235) mengatakan bahwa salah satu faktor internal yang menjadi problematika pembelajaran adalah kemampuan menyimpan perolehan bahan ajar, dalam hal ini sebagian besar mahasiswa menyatakan kurang baik dalam menyimpan perolehan hasil belajar.

\section{Menggali Hasil Belajar yang Tersimpan}

Mahasiswa akan memperkuat pesan baru dengan cara mempelajari kembali, atau mengaitkannya dengan bahan lama. Jika mahasiswa tidak mengaitkannya dengan bahan lama dan tidak mempelajari kembali materinya maka menyebabkan kurangnya kemampuan mahasiswa dalam menggali hasil belajar yang telah didapatkan dari materi tentang pembelajaran bahasa Jerman. Sejalan dengan teori Dimyati dan Sudjiono (2010:235) mengatakan bahwa salah satu faktor internal yang menjadi problematika pembelajaran adalah menggali hasil belajar. Pada problematika ini didapatkan sebagian besar mahasiswa menyatakan kurang baik dalam menggali hasil belajar yang telah didapatkan.

\section{Kemampuan Berprestasi}

Mahasiswa menunjukkan bahwa ia telah mampu memecahkan tugas-tugas belajar dengan mentransfer hasil belajar. Sejalan dengan teori Dimyati dan Sudjiono (2010:235) mengatakan bahwa salah satu faktor internal yang menjadi problematika pembelajaran adalah kemampuan berprestasi. Hal ini berdasarkan dari pengalaman sehari-hari di kampus bahwa mahasiswa menyatakan baik dalam perolehan hasil belajar yang didapat ketika menyelesaikan tugas atau latihan yang diberikan pada saat proses pembelajaran bahasa Jerman.

\section{Rasa Percaya Diri}

Dalam proses belajar diketahui bahwa unjuk prestasi merupakan tahap pembuktian yang diakui oleh pengajar dan teman sejawat mahasiswa. Sejalan dengan teori Dimyati dan Sudjiono (2010:235) mengatakan bahwa salah satu faktor internal yang menjadi problematika pembelajaran adalah rasa percaya diri. Hal ini sesuai dengan hasil angket yang didapatkan bahwa pada umunya mahasiswa masih banyak yang kurang percaya diri.

\section{Kebiasaan Belajar}

Dalam kegiatan sehari-hari ditemukan adanya kebiasaan yang kurang baik. Kebiasaan belajar tersebut antara lain: belajar teratur, belajar diakhir semester, dan menyia-nyiakan waktu belajar. Sejalan dengan teori Dimyati dan Sudjiono (2010:235) mengatakan bahwa salah satu faktor internal yang menjadi problematika pembelajaran adalah kebiasaan belajar. Menurut Harianto, H., Dalle, A., \& Anwar, M. 
(2021) bahwa gaya belajar juga dapat berpengaruh terhadap pembelajaran, khususnya dalam belajar bahasa Jerman. Dalam proses pembelajaran berlangsung tidak semua pelajar dapat memahami materi pelajaran dengan mudah, ada pelajar yang dengan mudah memahami materi dan ada pula yang begitu sulit untuk memahami materi pelajaran.

Hal ini dapat dilihat berdasarkan hasil angket bahwa pada umumnya mahasiswa memiliki kebiasaan belajarnya yakni belajar diakhir semester, hal ini juga sehubungan dengan problematika sebelumnya yaitu kemampuan menyimpan hasil belajar dan menggali kembali hasil belajar yang membuat mahasiswa sulit untuk mengingat kembali hasil pelajaran yang telah didapatkan.

10. Hubungan antara Impian dan Cita-cita

Pada umumnya setiap anak memiliki cita-cita, tetapi gambaran yang jelas tentang tokoh teladan bagi mahasiswa masih ada yang belum memiliki hubungan antara impian/cita-citanya dengan pembelajaran bahasa Jerman yang ditempuh, akibatnya mereka akan berprilaku ikut-ikutan. Sejalan dengan teori Dimyati dan Sudjiono (2010:235) mengatakan bahwa salah satu faktor internal yang menjadi problematika pembelajaran adalah hubungan antara impian dan cita-cita. Hasil dari angket yang didapatkan menyatakan bahwa ada hubungan antara impian dan citacita mahasiswa dalam pembelajaran bahasa Jerman.

\section{Gangguan Fungsi Alat Indera dan Alat Perseptual}

Kondisi tubuh yang sakit, kekurangan gizi dan vitamin dapat menyebabkan kurang maksimalnya proses belajar. Salah satu faktor internal yang menjadi problematika pembelajaran adalah gangguan fungsi alat indera dan alat perseptual. Berdasarkan hasil angket dapat dilihat ada beberapa mahasiswa yang mempunyai gangguan alat indera dan perseptual, namun pada umumnya tidak ada yang mempunyai gangguan alat indera dan perseptual.

12. Tenaga Pendidik

Pengajar memusatkan perhatian kepada mahasiswa, khususnya dengan kebangkitan belajar. Salah satu faktor eksternal yang menjadi problematika pembelajaran adalah Tenaga pendidik. Berdasarkan hasil angket ada beberapa mahasiswa yang masih merasa tenaga pendidik tidak melaksanakan tugasnya dengan baik pada proses pembelajaran bahasa Jerman, tetapi pada umumnya menyatakan baik.

\section{Sarana dan Prasarana Pembelajaran}

Ketersediaan sarana dan prasarana pada pembelajaran menghasilkan suasana belajar yang kondusif, hal ini bertujuan agar pembelajaran berjalan dengan lancar, teratur efektif dan efisien. Salah satu faktor eksternal yang menjadi problematika pembelajaran adalah sarana dan prasarana pembelajaran. Berdasarkan hasil angket, mahasiswa yang menyatakan bahwa sarana dan prasarana sudah mendukung seimbang dengan mahasiswa yang menyatakan bahwa sarana dan prasarana belum menduukung dalam proses pembelajaran. 


\section{Kebijakan Penilaian}

Keputusan hasil belajar merupakan puncak harapan mahasiswa. Secara kejiwaan mahasiswa terpengaruh atau tercekam tentang hasil belajarnya. Oleh karena itu, kampus dan pengajar diminta berlaku arif dan bijak dalam menyampaikan keputusan hasil belajar mahasiswa. Salah satu faktor eksternal yang menjadi problematika pembelajaran adalah kebijakan dalam penilaian. Dapat dilihat ada beberapa mahasiswa yang masih kemampuan dan hasil belajar yang didapatkan kurang sesuai

\section{Lingkungan Sosial}

Dalam lingkungan sosial ditemukan adanya kedudukan dan peranan tertentu, terjadi pergaulan seperti hubungan akrab, kerjasama, bersaing atau perkelahian. Sejalan dengan teori Dimyati dan Sudjiono (2010:235) mengatakan bahwa salah satu faktor eksternal yang menjadi problematika pembelajaran adalah limgkungan sosial. Berdasarkan hasil angket, lingkungan sosial dikampus pada umumnya mempengaruhi proses pembelajaran bahasa Jerman, tetapi masih ada sebagian mahasiswa menyatakan kurang berpengaruh dan tidak berpengaruh hubungan antara lingkungan sosial dan proses pembelajaran. Hal ini juga berkaitan dengan faktor internal sebelumnya yaitu rasa percaya diri, ketika mahasiswa merasa kurang nyaman di lingkungan kampus turut mempengaruhi rasa percaya diri mahasiswa pada saat proses pembelajaran.

\section{Lingkungan Keluarga}

Keluarga memiliki pengaruh besar terhadap pendidikan seorang anak., tetapi jika terdapat masalah-masalah dalam keluarga maka dapat menyita pikiran dan konsentrasi mahasiswa untuk fokus terhadap belajar. Salah satu faktor eksternal yang menjadi problematika pembelajaran adalah lingkungan keluarga. Dapat dilihat pada umumnya mahasiswa menyatakan berpengaruh hubungan antara lingkungan keluarga dengan proses pembelajaran.

\section{b. Angket Tertutup}

1. Kosakata

Penguasaan kosakata mahasiswa masih tergolong rendah, hal ini ditunjukkan berdasarkan data angket tertutup bahwa pada umumnya kurangnya pemahaman kosakata yang dimiliki mahasiswa, sehingga mahasiswa kesulitan dalam memahami materi yang disampaikan oleh pengajar, sulit menerjemahkan suatu teks, dan sulit dalam berkomunikasi. Menurut (Mawaresna, A., \& Anwar, M., 2020; Anding, M. F., Saud, S., \& Rijal, S., 2021; Nur, M., Burhanuddin, B., \& Mannahali, $M ;$ 2021) bahwa Penguasaan kosakata dapat menentukan keberhasilan siswa/mahasiswa dalam keterampilan berbahasa. Melalui kosakata tersebut, siswa/mahasiswa akan lebih mudah dalam mengungkapkan ide atau gagasan yang mereka miliki. Hal ini berarti semakin banyak kosakata yang dimiliki, maka akan semakin baik kualitas memahaminya. Sehingga dapat disimpulkan bahwa kurangnya penguasaan kosakata dapat menjadi penghambat dalam proses pembelajaran dan termasuk masalah utama yang dihadapi oleh mahasiswa. 


\section{Struktur Kalimat (gramatik)}

Berdasarkan data angket tertutup dapat disimpulkan mahasiswa sulit dalam menyusun kalimat karena kurangnya penguasaan konjugasi yang dimiliki oleh mahasiswa. Menurut

\section{Pengucapan/Pelafalan}

Latihan pengucapan kata bahasa Jerman sering diberikan oleh pengajar namun pada dasarnya kemampuan memahami mahasiswa yang rendah, latihan yang tidak memadai, serta minat siswa yang sangat rendah untuk memperlancar pengucapan dalam bahasa Jerman. Berdasarkan data angket tertutup hal tersebutlah yang menjadi hambatan dan akhirnya menjadi sebuah kesulitan bagi mahasiswa.

4. Rasa Malu

Keraguan terhadap apa yang akan dibicarakan disebabkan karena menganggap bahwa berbicara dalam bahasa Jerman sangatlah sulit sehingga jika melakukan kesalahan kecil akan membuat mahasiswa jadi malu dan pesimis untuk melakukan yang kedua kalinya lagi. Hal ini dapat dilihat dari data angket tertutup yang menyatakan mahasiswa merasa malu sehingga tidak percaya diri.

5. Hubungan antara Interaksi Pengajar dan Mahasiswa

Pengajar merupakan faktor penting dalam proses belajar mengajar terutama dalam menyampaikan materi dan menciptakan suasana kondisi kelas yang menyenangkan. Namun berdasarkan data angket tertutup dapat disimpulkan bahwa beberapa mahasiswa sulit memahami apa yang disampaikan oleh pengajar dalam bahasa Jerman.

6. Keterampilan mendengarkan (Höverstehen).

Keterampilan mahasiswa dalam mendengarkan bahasa Jerman pada umumnya masih tergolong rendah. Hal ini berdasarkan dari data angket tertutup mahasiswa, dikarenakan pengucapan penutur asli yang biasanya sangat cepat sehingga beberapa mahasiswa kurang mampu memahami makna dari kata yang didengarkan. Menurut (Azizah, L., Asri, W. K., \& Mannahali, M., 2020; Selviana, Y., Mannahali, M., \& Dalle, A., 2020; Usman, M., et.all 2020) bahwa mendengarkan adalah proses menerima suara melalui organ pendengaran di tubuh, sedangkan memahami adalah hasil pengolahan informasi yang diterima otak, dan dia mengerti apa yang disampaikan. Jadi, mendengarkan dan memahami adalah dua aktivitas yang terkait dengan apa yang disebut proses mendengarkan. Mendengarkan memang memiliki peran penting dalam proses pembelajaran bahasa. Namun, mendengarkan juga sulit keterampilan, terutama dalam mempelajari bahasa asing.

\section{KESIMPULAN}

Berdasarkan hasil penelitian dapat disimpulkan bahwa permasalahan/kendala yang sering dihadapi mahasiswa adalah berdasarkan faktor internal dan eksternal. Merujuk pada angket terbuka, faktor internal yang sangat mempengaruhi adalah kemampuan menyimpan perolehan bahan ajar, menggali 
hasil belajar yang tersimpan, dan kebiasaan belajar. Sedangkan pada faktor eksternal yang sangat mempengaruhi adalah sarana dan prasarana penunjang akademik, kebijakan penilaian tenaga pendidik, dan lingkungan sosial di kampus.

Selain itu, merujuk pada angket tertutup, masalah/kendala utama yang sangat mempengaruhi adalah kurangnya penguasaan kosakata yang dimiliki, kesulitan dalam struktur kalimat (gramatik), dan kurangnya kemampuan dalam pengucapan/pelafalan. Hal tersebut didukung oleh perolehan nilai dari hasil angket tambahan pada umumnya dari empat kompetensi berbahasa yang diajarkan, yaitu mendengar (Hören), menulis (Schreiben), membaca (Lesen) dan berbicara (Sprechen) mahasiswa mendapatkan nilai B+.

\section{DAFTAR PUSTAKA}

Amirudin, N. (2017). Problematika pembelajaran bahasa Arab. TAMADDUN: Jurnal Pendidikan dan Pemikiran Keagamaan, 1-12.

Anding, M. F., Saud, S., \& Rijal, S. (2021). Peningkatan Kosakata Bahasa Jerman Melalui Penggunaan Media Cerita Pendek. Interference: Journal of Language, Literature, and Linguistics, 2(1), 57-63.

Azizah, L., Asri, W. K., \& Mannahali, M. (2020). Development of Learning Media for Listening Skills of German Language Based on Web DaF (Deutsch als Fremdsprache) for Students High School in Makassar. Eralingua: Jurnal Pendidikan Bahasa Asing dan Sastra, 4(1).

Besse Wahida, M. P. I. (2017). Problematika Pembelajaran Bahasa Arab (Studi Kasus Terhadap Problematika Metodologis Pembelajaran Bahasa Arab Di Iain Pontianak). Jurnal Al-Astar Stai Mempawah, 7(1).

Dimyati dan Sudjiono. (2010). Belajar dan Pembelajaran. Jakarta: PT. Rineka Cipta.

Harianto, H., Dalle, A., \& Anwar, M. (2021). Pengaruh Pembelajaran Kooperatif dan Gaya Belajar Terhadap Keterampilan Menulis Bahasa Jerman Mahasiswa. Interference: Journal of Language, Literature, and Linguistics, 2(1), 49-56.

Mahasiswa dan Kebijakan Program Pembelajaran Bahasa Arab. Skripsi. FBS Universitas Negeri Makassar.

Mawaresna, A., \& Anwar, M. (2020). HUBUNGAN ANTARA PENGUASAAN KOSAKATA (WORTSCHATZ) DENGAN KEMAMPUAN MEMBACA MEMAHAMI (LESEVERSTEHEN) TEKS BAHASA JERMAN SISWA KELAS XI. Interference: Journal of Language, Literature, and Linguistics, 1(2), 153-158.

Nugroho, G. E. (2019). Pembelajaran bahasa Jerman pada peserta didik berkebutuhan khusus di SMA Negeri 9 Malang (Doctoral dissertation, Universitas Negeri Malang).

Nur, M., Burhanuddin, B., \& Mannahali, M. (2021). Hubungan Antara Penguasaan Kosakata dengan Keterampilan Menulis Puisi Bahasa Jerman. Interference: Journal of Language, Literature, and Linguistics, 2(1), 64-70.

Pabumbun, A. R. (2019). Problematika Pembelajaran Kemampuan Menyimak Bahasa Jerman Siswa kelas XI SMA Negeri 11 Makassar. Skripsi. FBS Universitas Negeri Makassar.

Selviana, Y., Mannahali, M., \& Dalle, A. (2020). HUBUNGAN ANTARA PENGUASAAN KOSAKATA DENGAN KEMAMPUAN MENYIMAK BAHASA JERMAN SISWA 
KELAS XI BAHASA. Interference: Journal of Language, Literature, and Linguistics, 1(2), 148-152.I

Setiyawan, A. (2019). Problematika Keragaman Latar Belakang Pendidikan

Usman, M., Dalle, A., Azizah, L., \& Ernawati, E. (2020). EFEKTIVITAS PENGGUNAAN LABORATORIUM BAHASA DALAM PEMBELAJARAN KETERAMPILAN MENYIMAK BAHASA JERMAN MAHASISWA PRODI PENDIDIKAN BAHASA JERMAN FBS-UNM. Interference: Journal of Language, Literature, and Linguistics, 1(1).

Wibowo, T. (2010). Problematika Mahasiswa input non pesantren dan non Aliyah dalam belajar bahasa Arab di jurusan sastra Arab Universitas Negeri Malang. Skripsi Universitas Negeri Malang.

Yusri, Y., Rosida, A., Jufri, J., \& Mantasiah, R. (2018). Efektivitas Penggunaan Media Youtube Berbasis Various Approaches dalam Meningkatkan Motivasi Belajar Bahasa Inggris. Eralingua: Jurnal Pendidikan Bahasa Asing dan Sastra, 2(2). 